\title{
Social Functions of Tuvan Folk Sports
}

\author{
Kherel-ool D-N. Oorzhak* \\ and Bolat A. Shagzhy \\ Tuvan State University \\ 36 Lenin Str., Kyzyl, Republic Tyva, 667000, Russia
}

Received 19.07.2016, received in revised form 25.09.2016, accepted 13.11.2016

There are more than 40 nations in the Russian Federation. They differ in their state status and socioeconomic development and act as the main creators of the human cultural fund.

The study attempts to discover social functions of the Tuvan folk sports ("Khuresh" wrestling, archery, horse racing). The systemic analysis considers the problem as a social phenomenon regarded in the context of all aspects of public life.

Person-directed education and development are social functions providing a great opportunity not only for physical development and athletic improvement; they also imply moral, aesthetic, intellectual, and labor education, as well as spiritually-moral qualities.

Social functions implementation depends not only on the traditional sports but also on the orientation of the entire educational system and social development. Educational potential results not only through educational opportunities themselves, but through a system of social relations emerging in the sphere of physical culture and sports.

Keywords: physical education, national culture, education, "Khuresh" wrestling, action games, the spiritual, the moral.

DOI: 10.17516/1997-1370-2016-9-12-2995-3000.

Research area: pedagogy, sociology.

\section{Introduction}

The issues of the national culture are currently urgent for the theory of culture. First of all, it should be noted that compared with other social actors the nations (the peoples) are the main creators of the human cultural fund, the main actors of culture. Thus, the cultural diversity in the world is linked to the peoples. Moreover, they are historically the first subjects of culture, because originally the culture of mankind existed only in the form of traditional cultures as cultures of local societies (Isakova, 1988, p. 9).
Many nations reside in the Russian Federation. They are not equal in number, state status, and socio-economic development. At present, it is impossible to equalize their sociocultural level. Therefore, it is necessary to do the research on these peoples' experience and cultures.

Culture can embody the way of life of individuals, social groups, or society as a whole. Every nation, regardless of a stage of historical development, adapts and develops its culture. The people have equal rights, and their opinions

(C) Siberian Federal University. All rights reserved

* Corresponding author E-mail address: herel-ool@mail.ru 
about their culture can be not only positive but critical as well.

A great variety of definitions of culture indicates the complexity of the problem and an increased interest of the representatives of various fields of knowledge. To understand the culture of any people is, in a sense, to understand the people, their traditions and ideals, concerns and hopes. Culture is a living and clear evidence of the people's social development, their spiritual perfection (Mezhuev, 1968, p. 3). It is known that cultural values originally had certain functional meaning. These functions cannot be strictly differentiated due to their complex nature. It is not possible to precisely define the functions of a particular type of culture. Therefore, it is a matter of scientific accuracy to talk about the prevalence of a particular functional potential in cultural values (Kharcheva, 2000, p. 79).

\section{Theoretical framework}

To understand the nature of national culture, its structure and social function, content and form, as well as regularity of its origin, formation and development it is necessary to have a clear understanding of what culture is in general. There are more than 400 definitions of culture. So, the concept of "culture" will not be dwelt upon as the purpose of the article is different.

However, the present research attempts to discover and identify the solutions of complex theoretical-cultural and ethno-pedagogical problems of traditional physical culture. In this regard, firstly, the paper presents the status of the Tuvan people's national physical culture regarding its social ethno-pedagogical basis. Secondly, it focuses on the peculiarities of its development and meaning in different historical times, its connection with the people's life, customs, and traditions. Thirdly, it analyzes a structural-functional and pedagogical content of the national means of physical culture. These resulted in the development of a special course "Physical Culture as a Kind of the Tuvan People's Culture" (Oorzhak, 1995, p. 110).

Physical culture and sport are of great social and socio-pedagogical value in the life of a person and society. The main social effects and importance of physical education and sport are manifested in personal and social aspects. A personal aspect highlights the impact of physical culture and sports on an individual as it shows his / her perfection caused by physical exercises. A social aspect shows the improvement of a person's social activity under the beneficial influence of physical culture and sports and his / her contribution to social progress and social production to satisfy the needs of the society.

As a part of the national culture the people's traditional physical culture is put into practice to satisfy a human's certain needs (for example, socio-communicative needs as it expands contacts, mobility, change of social status, and modification of social roles).

\section{Methods}

As the main principle of this research, the systemic analysis provides for considering the national culture both in the focus of its historical development and in the focus of interaction and spatial coverage, the national culture being a social phenomenon which can be comprehended in the context of all aspects of social life, as well as of the theory of an individual's social production and reproduction in the course of his her activities. The analysis of the national culture employs the principle of historicism as a method of research facilitating a retrospective consideration of a historical path of the Tuvan people's physical culture development in general, its structure, interrelation with other cultures, their influence on its status and development and determination of an ethno-pedagogical basis of the national means of physical culture. 
The object of the folk sports education is an individual (not only an athlete but also a person, visiting and participating in mass competitions). Those who put this educational function into practice are teachers, coaches, instructors, and managers. At that student-athletes are not passive objects. They are actively involved in sports activities while searching for creative ways to achieve the best results. Their diligence and initiative, in their turn, affect the coaches and teachers. Thus, a subject-object system of education is formed in the process of sports training.

\section{Statement of the problem}

The social functions are person-directed education and development. The Tuvan folk sports ("Khuresh" wrestling, archery, horse racing) provide a great opportunity not only for physical development and athletic improvement; they also imply moral, aesthetic, intellectual, and labor education. They aim at ensuring great opportunities for cultivation a person's spiritualand-moral qualities (Oorzhak, 1995, p. 112).

Traditional physical culture with its folk sports (such as Tuvan "Khuresh" wrestling, for example) is an inseparable component of the standard of living that implies the degree of satisfaction of human needs, the provision of consumer goods, including the objective conditions for physical culture and sports for every member of the society.

Physical culture and national sports are parts of a life style, the manner of exercising an individual or group activity. A person's attitude to physical culture and sport is manifested in his / her active systemic exercise. In Tuva Republic the number of regular active sports participants is approximately $8.3 \%$ of the total population, of which $7.8 \%$ are preschool children, $4.5 \%$ are adults, $35 \%$ are pupils and students (KaraTonnug, 2014, p. 32 ).
Passive spectator observation and indifference are forms of a person's behavior; they characterize the quality of a human's life according to the influence of physical culture and sport on a person's development and perfection.

The increase of social production causes the growth of public consumption funds and improvement of personal well-being. This, in turn, significantly determines the extent and main directions of physical culture and sports in the country, guarantees the population's needs for physical culture and sports, rational activization of motion providing for health and high performance, creative lifetime and good health.

The main social functions of the Tuvan folk sports are educational, humanistic, educational, logistical-and-production functions and a function of social relations improvement. A leading social function is educational. Its effectiveness results from interrelation of education with other aspects of social life, a combination of physical education with other components of a complex system of education. Along with physical education a person receives moral, mental, labor, aesthetic and patriotic education. The systematic process of going in for folk sports favours a person's many-sided education.

An individual's education in the sphere of physical culture and sport includes:

- extension of moral, ideological, humanistic influence of social environment to all aspects of physical culture and sports activities and various forms, types and methods of health and sport promotion;

- application of a range of economic, social and moral conditions of health, fitness and sports activities;

- purposeful application of various forms, means and methods of physical education as a specific sphere of education and sociopedagogical activities. 
Active engagement of the Tuvan folk sports develops a person's valuable social qualities, such as humanistic conviction, recognition of the paramount values and priority of an individual's rights and freedoms, stability of friendly and respectful relations towards people.

The systematic process of going in for folk sports develops a person's social activity. Top athletes are actively involved in electoral public work, diligently performing the functions and duties of judges, coaches, instructors, team captains, and heads of the groups, clubs and societies.

Humanistic morality is actively implemented and cultivated in friendly cooperation in sports, athletic teams and groups, as well as between the athletes and a coach, sports partners and rivals if based on consciously and conscientiously observed rules, customs, and traditions which are integral to the ethics of social behavior and sports ethics.

Educational functions are realized in the process of physical training and sports activities in their direct and indirect forms as a person learns a lot and acquires new skills. Enthusiasts are looking for and willing to assimilate additional knowledge from different sciences contributing to success in health, fitness and sports activities. Thus, cognitive activity and creative use of obtained and accumulated knowledge are developed.

The function of formation, regulation and improvement of public relations is one of general and social functions of the Tuvan folk sports. This function is realized in the following main directions:

- socio-political relations introduce the masses to public self-administration, encourage development and democracy strengthening;

-national relations develop and improve.

Internationalizing impact of the national sports of the peoples of Southern Siberia on all residents of the region, Mongolia, and Russia is worth being mentioned. So, nowadays "Khuresh" competition, which is called "Friendship", is held annually for Russian, Ukrainian, Buryat, Yakut, Kazakh, Uzbek, Tatar, Mongol, Khakass, Altaian wrestlers. Even the Japanese tried khuresh. Horse races are held with the participation of the Mongols and Russians. In this respect the national sports of the indigenous peoples of Siberia deserve the most careful attention and study, since they have an internationalizing focus and contribute to a person's adaptation and humanization in difficult climatic conditions of Siberia.

Folk means of physical training as a part of culture fulfill the functions of socialization and social mobility, and the function of integration.

The function of a person's socialization by folk sports in modern Tuvan society comes from the belief that regular active classes, supported by moral and religious ideas, develop personal qualities. It is believed that socialization is accomplished through two interrelated processes - conviction (belief) and acquisition (formation). The idea of conviction is reflected in the theory of physical training with its issue of understanding of positive and negative behavior. The formation means creation of a specific example, a model behavior for the socialized and the "system of beliefs" that lies in its basis. Thus, both mechanisms act in the national sports, the mechanisms being socially desirable models of behaviour and attitudes inherent to them only.

The function of integration is a means of achieving harmonious integration of people with the society as well as their identification with it. Socialization is a means for integrating a human into the system of beliefs and behavior developed by the culture. This purpose can be achieved by integrating a person in the society, which, in its turn, is integrated into this cultural environment. A person's integration in the society takes place, firstly, by means of the development of the 
feelings of communality and fellowship peculiar for a socio-emotional function. These feelings are a source of integration of sports clubs members, teams of educational institutions, establishments, cities and districts of Tuva Republic in the society. Secondly, integration is achieved through the development of group and non-group consciousness. At that the team is identified as a separate in-group whereas the other team is identified as an out-group.

A complex effect of influence of active participation in folk sports on a person is many-sided and broad-ranging. It favours the development of a person's social activity, his / her psychological preparedness and physical perfection. An individual's social activity is expressed in such indicators as socialization, involvement in social life; ability to adopt new specific social roles, norms and values, value orientations, ideals oflife, activesociallifeposition; sociability, relationships in social community, development of interpersonal communication (which is especially evident among the members of a sports team, group), collectivism; production and employment efficiency.

\section{Discussion}

Regular participation in folk sports leads to a transfer of special knowledge. Its other meaning, which is equally important, is the acquisition of values and their practical development. These values are formed in the course of a person's life in the social environment. However, traditional sports can bring people together; they help to develop their common interests and feelings, worldview and attitudes. Folk sports with their positive and emotionally stimulating energy (the energy destroying extra energy) lead to a person's subjectively valuable emotions, developing certain traits and characteristic features. Folk sports does not require external coercion; it gives way to internal factors: ethical and aesthetic, as sport contributes to their development. Thus, one of the most important functions of sport is the development of the people's social life (Oorzhak, 1995, p.110).

Physical culture and sport unite numerous and diverse groups of people in voluntary sports organization. Management and implementation of these organizations' activities are carried out by the elected bodies.

Sports events contribute to rapprochement and mutual understanding, establishment and strengthening of friendly partnership and ties between different ethnic communities. Sports interethnic contacts contribute to rapprochement of national cultures, each nation's spiritual and moral development acceleration. Communication of athletes can help to overcome negative attitudes and prejudices between people of different ethnic groups and countries.

Folk sports contribute to the improvement of general and special working efficiency, social biogenic adaptation to environmental conditions and ensure a person's readiness to social activities.

\section{Conclusion}

Thus, the final result of the social function implementation depends not only on folk sports, but also on the orientation of the entire system of education and social development. Folk sports exercise their educational opportunities not through themselves only, but through a system of social relations, including those emerging in the field of physical culture and sport.

General socio-economic and socio-cultural effectiveness of the Tuvan folk sports is based on a positive influence of active exercise on a person and mass development of physical culture and sports movement. Being an integral component of lifestyle of the society, social communities, groups and individuals, they manifest themselves in modern society. Moreover, a person's 
physical culture is increasingly actualized in a progressive civilized society. This conscious and purposeful, rationally organized, optimally normalized and scientifically managed activity provides for the development of a person's physical body. In general, folk sports contribute to the improvement of social needs and qualities of human life.

\title{
References
}

Isakova, N.V. (1988). Cul'tura narodov Severa [The Culture of the Peoples of the North]. Novosibirsk, Nauka, 156 p.

Kara-Tonnug, V.M. (2014). Otchet zaveduiushchego obshchim otdelom Ministerstva po delam molodezhi i sporta Respubliki Tyva [The Report of the Head of the Administration Department of the Ministry of Youth Affairs and Sport of the Republic of Tuva]. Kyzyl, 32 p.

Mezhuev, V.M. (1977). Cultura i istoriia [Culture and History]. Moscow, Politizdat, 199 p.

Oorzhak, H.D-N. (1995). Pedagogicheskoe soderzhanie fizicheskoi kul'tury narodov Iuzhnoi Sibiri [Pedagogical Content of Physical Culture of the Peoples of Southern Siberia]. Kyzyl, Tuva Book Publishing House, $227 \mathrm{p}$.

Kharcheva, V.G. (2000). Osnovy sotsiologii [The Basics of Sociology]. Moscow, Logos, 302 p.

\section{Социальные функции тувинского народного спорта}

\author{
Х.Д-Н. Ооржак, Б.А. Шагжи \\ Тувинский государственный университет \\ Россия, 667000, Республика Тыва, Кьзыл, \\ ул. Ленина, 36
}

На территории Российской Федерации проживают более 40 различных народов, которые отличаются по своему государственному статусу и уровню социально-экономического развития и выступают основными создателями человеческого культурного фонда.

В настоящем исследовании предпринята попытка определить социальные функиии тувинских народных видов спорта (национальная борьба хуреш, стрельба из лука, верховая езда). Системный анализ позволяет рассматривать проблему как социальный феномен, изучаемый 8 контексте различных аспектов общественной жизни.

Человекоориентированное образование и развитие представляют собой социальные функиии, направленные не только на совершенствование физических и атлетических навыков, но также подразумевающие формирование моральных, эстетических и интеллектуальных качеств и обучение труду.

Реализация социальных функиий зависит не только от традиционных видов спорта, но также от ориентирования всей системы образования и социального развития. Образовательный потенциал реализуется не только через образовательные возможности, но и через систему сочиальных отношений, возникающих в сфере физической культуры и спорта.

Ключевые слова: физическая культура, образование, национальная культура, наииональная борьба хуреш, активные игры, духовное, моральное.

Научная специальность: 13.00.00 - педагогические науки, 22.00.00 - соииологические науки. 